\title{
Triple-Negative Breast Cancer: The Progress of Targeted Therapies and Future Tendencies
}

\author{
CHRISTOS DAMASKOS ${ }^{1 *}$, ANNA GARMPI ${ }^{2 *}$, KONSTANTINOS NIKOLETTOS $^{1}$, MICHAIL VAVOURAKIS ${ }^{1}$, \\ EVANGELOS DIAMANTIS ${ }^{3}$, ALEXANDROS PATSOURAS ${ }^{4}$, PARASKEVI FARMAKI ${ }^{5}$, AFRODITI NONNI ${ }^{6}$, \\ DIMITRIOS DIMITROULIS ${ }^{1}$, DIMITRIOS MANTAS ${ }^{1}$, EFSTATHIOS A. ANTONIOU ${ }^{1}$, \\ NIKOS NIKOLETTOS ${ }^{7}$, KONSTANTINOS KONTZOGLOU $^{1}$ and NIKOLAOS GARMPIS ${ }^{1}$ \\ ${ }^{1}$ Second Department of Propedeutic Surgery, Laiko General Hospital, \\ Medical School, National and Kapodistrian University of Athens, Athens, Greece; \\ ${ }^{2}$ First Department of Propedeutic Internal Medicine, Laiko General Hospital, \\ Medical School, National and Kapodistrian University of Athens, Athens, Greece; \\ ${ }^{3}$ Department of Endocrinology and Diabetes Center, G. Gennimatas General Hospital, Athens, Greece; \\ ${ }^{4}$ Medical School, National and Kapodistrian University of Athens, Athens, Greece; \\ ${ }^{5}$ First Department of Pediatrics, Agia Sofia Children's Hospital, \\ National and Kapodistrian University of Athens, Athens, Greece; \\ ${ }^{6}$ First Department of Pathology, Medical School, National and Kapodistrian University of Athens, Athens, Greece; \\ ${ }^{7}$ Obstetric - Gynecologic Clinic, Medical School, Democritus University of Thrace, Alexandroupolis, Greece
}

\begin{abstract}
Triple-negative breast cancer (TNBC) is characterized by a lack of expression of estrogen receptor (ER), progesterone receptor $(P R)$ and human epidermal growth factor receptor 2 (HER2) and unfortunately is not associated with good prognosis. Treatment of breast cancer mainly depends on chemotherapy, due to the lack of specifically approved targeted therapies for TNBC. It is of paramount importance to find new therapeutic approaches, as resistance to chemotherapy frequently occurs. Herein, we present clinical studies published within the last five years, in order to reveal possible targeted therapies against TNBC. We aimed to discuss factors against $T N B C$, such as tyrosine kinase inhibitors, anti-androgens, poly ADP-ribose polymerase-1 (PARP-1) inhibitors, anti-angiogenic factors, immune checkpoints and histone deacetylase inhibitors
\end{abstract}

This article is freely accessible online.

*These Authors contributed equally to this study.

Correspondence to: Dr. Christos Damaskos, MD, M.Sc., Ph.D., Second Department of Propedeutic Surgery, Laiko General Hospital, National and Kapodistrian University of Athens, Medical School, 17 Agiou Thoma Street, Athens, 11527, Greece. Tel: +30 6948467790,e-mail: x_damaskos@yahoo.gr

Key Words: Triple-negative, breast cancer, targeted, therapies, review.
(HDACI). Furthermore, the PI3K/AKT/mTOR pathway seems to be a promising field for the development of new anti-TNBC targeted therapies. Data from 18 clinical trials with patients suffering from TNBC were summarized and presented descriptively.

Breast cancer is one of the most common cancers in females, comprising heterogeneous tumors with a variety of biological features, clinical course, prognosis and response to therapy $(1,2)$. In 2017 , triple-negative breast cancer (TNBC) accounted for about $15 \%$ of all the new cases of breast cancer in the United States (3-7). Many different epidemiological studies have revealed that TNBC was more likely to arise among females characterized by early menarche, higher waist to hip ratio, higher parity, shorter duration of breast feeding, higher body mass index, and was more common among pre-menopausal patients (8). TNBC is a disease defined by the absence of human epidermal growth factor receptor 2 (HER2) and hormone receptors $(\mathrm{HR})$, specifically the progesterone $(\mathrm{PR})$ and the estrogen receptor (ER) (9) (Figure 1). There are at least 6 different subtypes, which demonstrate different biological behavior, including the basal-like 1 and 2 (BL-1 and BL2), mesenchymal (M), mesenchymal stem-like (MSL), immunomodulatory (IM), luminal androgen receptor (LAR) and unstable subtype $(7,10)$. 
TNBC is characterized by poorer diagnosis compared to the other types of breast cancer, with a more aggressive clinical behavior (11-14). Central nervous system and visceral metastases appear at higher incidence and in shorter period of time in this specific type of cancer (15-17). In addition, cerebral, hepatic and pulmonary metastases are more frequent in TNBC, than in other luminal subtypes (18, 19). The greatest risk of recurrent disease occurs in the first 2-3 years after diagnosis and is at minimal after 8 years (4, 20 , 21). Cytotoxic chemotherapy still remains the main treatment for TNBC disease, along with surgery and/or radiotherapy, although $60 \%$ of TNBC patients show minimal or no response to the aforementioned treatment (22-24). Thus, various studies and clinical trials are being conducted, in order to provide new targets and improve prognosis. Androgen targeted therapy, anti-angiogenetic factors, histone deacetylase inhibitors, immune checkpoint inhibitors, PARP inhibitors and the PI3K/AMT/TOR pathway have been proposed as possible targets for the treatment of TNBC (25-34).

The present study provides an up-to-date review which focuses on the progress made in the field of targeted therapies for TNBC in the last five years.

\section{Materials and Methods}

A literature search was conducted in MEDLINE (via PubMed) and COCHRAINE library in order to retrieve articles published during the period between 2015-2019. The search strategy was based on the use of keywords such as triple-negative breast cancer, targeted therapies, clinical trials and metastases. The PRISMA approach was used for the selection of the publications included in the review. A total of 358 records were identified. Following removal of the duplicates 357 records remained. These were screened and 339 were excluded because they were only abstracts or did not include clinical trials. Furthermore, articles were excluded because TNBC patients were neither the only group included, nor were analyzed separately in the clinical study. The full-text articles assessed for eligibility were 18 and none of them was excluded. The inclusion process is presented in Figure 2.

\section{Results}

Anti-angiogenic factors. High expression of VEGF has been reported in TNBC $(35,36)$. VEGF has been shown to induce high tumor cell proliferation in mice models of breast cancer (37). As demonstrated in various clinical and experimental studies, the most significant angiogenic factor for breast cancer is VEGF (35). In human breast cancer, the combination of mutant p53 with high labels of VEGF, is associated with poor clinical outcome (38).

In 2016, Ferrero et al., reported a single-arm multicenter phase II study which included 64 patients with advanced TNBC (Table I, Entry 1). Patients received treatment with 4-

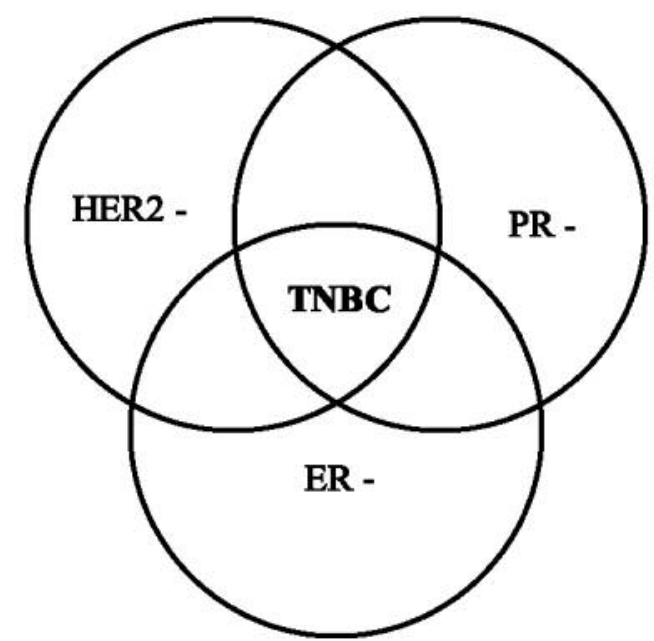

Figure 1. Triple-negative breast cancer. HER2: Human epidermal growth factor receptor 2; PR: progesterone receptor; ER: estrogen receptor; TNBC: triple-negative breast cancer.

week cycles with capecitabine $\left(800 \mathrm{mg} / \mathrm{m}^{2}\right.$ twice on days 1 $5,8-12,15-19)$, paclitaxel $\left(80 \mathrm{mg} / \mathrm{m}^{2}\right.$ on days 1,8 and 15 for maximum of 6 cycles) and bevacizumab $(10 \mathrm{mg} / \mathrm{kg}$ on days 1 and 14) every 4 weeks until unacceptable toxicity or disease progression. It was shown that this triple regimen had efficient antitumor activity with acceptable levels of toxicity (39).

In 2016, the results of an international randomized phase III trial of 2,591 female patients with centrally operable primary invasive TNBC was published (Table I, Entry 2). Chemotherapy alone or combined with bevacizumab at a dose equivalent to $5 \mathrm{mg} / \mathrm{kg}$ weekly was administrated to patients. Bell's study compared the two treatments and suggested that there is no significant benefit from the addition of bevacizumab in non-advanced TNBC (40).

One year later, a phase II study with 46 patients examined the efficacy of paclitaxel, carboplatin and bevacizumab $10 \mathrm{mg} / \mathrm{kg}$ intravenous on day 1 and 15 of a 28-day cycle against metastatic TNBC (Table I, Entry 3). It was shown that this regimen offered clinical response without the serious adverse events associated to bevacizumab (24).

In 2018, a phase II clinical trial including 55 female patients, aged between 33 to 83 years old, with invasive TNBC was conducted (Table I, Entry 4). Nabpaclitaxel and $10 \mathrm{mg} / \mathrm{kg}$ IV bevacizumab at days 1 and 15 , along with maintenance therapy with the same dose of bevacizumab with erlotinib was administered to patients. According to Symonds et al., the combination treatment described above did not increase progression-free survival, as expected, but the maintenance therapy offered a break from chemotherapy (41). 

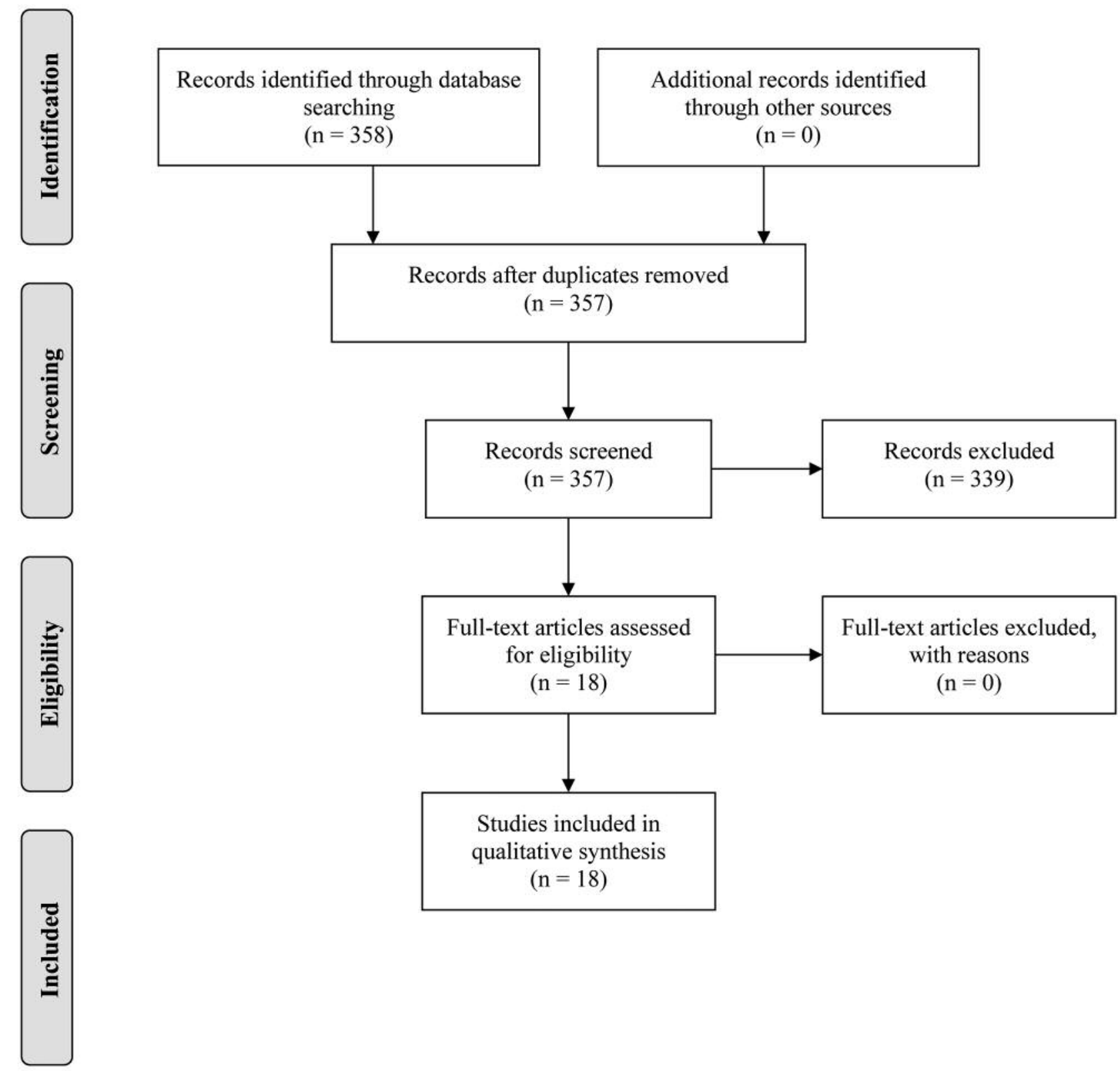

Figure 2. Prisma flow diagram for the current literature review.

Next year, Mery et al., treated 45 female TNBC patients with a median age of 62 years, with paclitaxel plus $10 \mathrm{mg} / \mathrm{kg}$ bevacizumab on days 1 and 15 (Table I, Entry 5). According to the results, bevacizumab proved to be beneficial to patients by prolonging median progression-free survival with limited toxicity (42).

Immune checkpoint inhibitors. PD-1 receptor is expressed on the surface of T-reg cells. Both lymphocytes and cancer cells bind to PD-1 via its ligand named PD-L1. PD-L1 is not found in normal epithelial cells $(43,44)$. Their binding leads to inhibition of $\mathrm{T}$ killer cell action against cancer cells and decreased production of inflammatory cytokines. Thus, $\mathrm{T}$ killer and cancer cells interact. The inhibitors of PD-1 and PD-L1 inhibit the immune checkpoints mentioned above and improve immune response induced by $\mathrm{T}$ killer cells (44).

TNBC expresses relatively high levels of PD-L1, mostly on immune [tumor infiltrating lymphocytes (TILs)] cells and less frequently on cancer cells (45). Thus, TNBC is a perfect candidate for trials with anti-PD-1/PD-L1 agents (46). 
Table I. Clinical trials with targeted therapies conducted in patients with Triple-Negative Breast Cancer.

\begin{tabular}{|c|c|c|c|c|c|c|}
\hline Entry & Author & Year & Study & Patients & Therapy & Conclusion \\
\hline 1 & $\begin{array}{l}\text { Ferrero } \\
\text { et al. }(39)\end{array}$ & 2016 & $\begin{array}{c}\text { Single-arm multicenter } \\
\text { phase II } \\
\text { study }\end{array}$ & $\begin{array}{l}62 \text { patients with metastatic } \\
\text { or locally advanced TNBC } \\
\text { without previous treatment } \\
\text { with chemotherapy }\end{array}$ & $\begin{array}{l}\text { Paclitaxel, capecitabine } \\
\text { and bevacizumab } \\
10 \mathrm{mg} / \mathrm{kg} \text { on days } \\
1 \text { and } 14 \text { every } 4 \text { weeks }\end{array}$ & $\begin{array}{c}\text { This triple regimen } \\
\text { showed antitumor } \\
\text { efficacy with an OR } 77 \% \\
{[95 \% \text { Confidence interval }} \\
(95 \% \mathrm{CI})=66-88 \%] \text { and } \\
\text { with acceptable toxicity }\end{array}$ \\
\hline 2 & $\begin{array}{c}\text { Bell } \\
\text { et al. }(40)\end{array}$ & 2017 & $\begin{array}{c}\text { International open-label } \\
\text { randomized } \\
\text { phase III trial }\end{array}$ & $\begin{array}{l}2591 \text { female patients } \\
\text { with operable primary } \\
\text { invasive TNBC }\end{array}$ & $\begin{array}{l}\text { Chemotherapy alone or } \\
\text { combined with } \\
\text { bevacizumab at dose } \\
\text { equivalent to } \\
5 \mathrm{mg} / \mathrm{kg} \text { weekly }\end{array}$ & $\begin{array}{c}\text { The combination of } \\
\text { chemotherapy with } \\
\text { bevacizumab did not } \\
\text { demonstrate significant } \\
\text { benefit IDFS } 80 \% \\
\text { (95\%CI=77-82\%) } \\
\text { compared to } \\
\text { chemotherapy alone } 77 \% \\
\text { (95\% CI }=75-79 \%)\end{array}$ \\
\hline 3 & $\begin{array}{l}\text { Saloustros } \\
\text { et al. (24) }\end{array}$ & 2018 & Phase II study & $\begin{array}{c}46 \text { patients of median age } \\
54 \text { years old suffering from } \\
\text { mTNBC }\end{array}$ & $\begin{array}{l}\text { Paclitaxel, carboplatin } \\
\text { and bevacizumab } \\
10 \mathrm{mg} / \mathrm{kg} \text { intravenous } \\
\text { on day } 1 \text { and } 15 \text { of } \\
28 \text { days cycle }\end{array}$ & $\begin{array}{c}\text { This regimen demonstrated } \\
\text { efficient antitumor action } \\
\text { with an ORR } 65.2 \% \\
(95 \% \mathrm{CI}=52.9-80.4 \%)\end{array}$ \\
\hline 4 & $\begin{array}{l}\text { Symonds } \\
\text { et al. (41) }\end{array}$ & 2018 & Phase II clinical trial & $\begin{array}{l}55 \text { female patients aging } \\
\text { between } 33 \text { to } 83 \text { years } \\
\text { old with invasive TNBC }\end{array}$ & $\begin{array}{c}\text { Nab-paclitaxel and } \\
\text { bevacizumab } 10 \mathrm{mg} / \mathrm{kg} \\
\text { IV at days } 1 \text { and } 15 \text { and } \\
\text { maintenance therapy with } \\
\text { the same dose of } \\
\text { bevacizumab with erlotinib }\end{array}$ & $\begin{array}{c}\text { Even though PFS }(9.1 \\
\text { months, } 95 \% \mathrm{CI}=7.2-11.1) \\
\text { did not increase as } \\
\text { expected, these regimens } \\
\text { demonstrated tolerable } \\
\text { toxicity and similar } \\
\text { efficacy with other } \\
\text { regimens. } \\
\text { The maintenance therapy } \\
\text { offered a break from } \\
\text { chemotherapeutic treatment }\end{array}$ \\
\hline 5 & $\begin{array}{c}\text { Mery } \\
\text { et al. }(42)\end{array}$ & 2019 & $\begin{array}{l}\text { Single-center } \\
\text { retrospective study }\end{array}$ & $\begin{array}{l}45 \text { female patients of median } \\
\text { age } 62 \text { years old suffering } \\
\text { from mTNBC }\end{array}$ & $\begin{array}{c}\text { Paclitaxel plus } \\
\text { bevacizumab } 10 \mathrm{mg} / \mathrm{kg} \\
\text { on days } 1 \text { and } 15\end{array}$ & $\begin{array}{c}\text { Bevacizumab offered } \\
\text { significant benefit as } \\
\text { the median PFS was } 8.4 \\
\text { months }(95 \% \text { CI=6-9.6) } \\
\text { with limited toxicity }\end{array}$ \\
\hline 6 & $\begin{array}{l}\text { Nanda } \\
\text { et al. }(47)\end{array}$ & 2016 & $\begin{array}{l}\text { Nonrandomized, } \\
\text { multicohort, } \\
\text { phase Ib study }\end{array}$ & $\begin{array}{l}32 \text { women with positive } \\
\text { PD-L1 TNBC aging } \\
\text { between } 29 \text { to } 72 \text { years old }\end{array}$ & $\begin{array}{l}\text { IV administration } \\
\text { of pembrolizumab } \\
10 \mathrm{mg} / \mathrm{kg} \text { every } \\
2 \text { weeks }\end{array}$ & $\begin{array}{c}\text { The use of pembrolizumab } \\
\text { shows significant clinical } \\
\text { antitumor activity with } \\
\text { ORR }=18.5 \% \\
{[95 \% \text { CI }=18.5(6.3 \text { to } 38.1)} \\
\text { with mild toxicity }\end{array}$ \\
\hline 7 & $\begin{array}{c}\text { Dirix } \\
\text { et al. }(48)\end{array}$ & 2017 & $\begin{array}{c}\text { Open-label, } \\
\text { international, phase } \\
\text { I trial }\end{array}$ & $\begin{array}{l}168 \text { female patients with } \\
\text { metastatic breast cancer, } \\
\text { including } 58 \text { with TNBC and } \\
\text { ECOG performance } \\
\text { status }<2\end{array}$ & $\begin{array}{l}\text { IV administration of } \\
\text { avelumab } \\
10 \mathrm{mg} / \mathrm{kg} \text { every } \\
2 \text { weeks }\end{array}$ & $\begin{array}{c}\text { In the TNBC population, } \\
\text { avelumab demonstrated } \\
\text { antitumor activity } \\
\text { with ORR }=5.2 \%, \\
\text { [95\% } \\
\text { with tolerable safety profile }\end{array}$ \\
\hline 8 & $\begin{array}{c}\text { Adams } \\
\text { et al. (49) }\end{array}$ & 2019 & $\begin{array}{l}\text { International, } \\
\text { multicohort, } \\
\text { open-label, } \\
\text { phase II study }\end{array}$ & $\begin{array}{l}170 \text { female patients between } \\
28 \text { to } 85 \text { years old with } \\
\text { mTNBC having already } \\
\text { received previous } \\
\text { chemotherapy schemes }\end{array}$ & $\begin{array}{c}200 \text { mg Pembrolizumab } \\
\text { IV over } 30 \text { min every } \\
3 \text { weeks for maximum } \\
2 \text { years }\end{array}$ & $\begin{array}{c}\text { Pembrolizumab } \\
\text { demonstrated antitumor } \\
\text { activity especially in } \\
\text { patients with PD-L1- } \\
\text { positive mTNBC with } \\
\text { ORR }=5.7 \% \\
(95 \% \text { CI }=2.4-12.2)\end{array}$ \\
\hline
\end{tabular}


Table I. Continued

\begin{tabular}{|c|c|c|c|c|c|c|}
\hline Entry & Author & Year & Study & Patients & Therapy & Conclusion \\
\hline 9 & $\begin{array}{l}\text { Adams } \\
\text { et al. }(50)\end{array}$ & 2019 & $\begin{array}{l}\text { International, } \\
\text { multicohort, } \\
\text { open-label, } \\
\text { phase II study }\end{array}$ & $\begin{array}{c}84 \text { female patients aging } \\
\text { between } 26 \text { to } 91 \text { years old, } \\
\text { ECOG performance status } \\
<2 \text { and diagnosed with positive } \\
\text { PD-L1 mTNBC without } \\
\text { previous systematic treatment }\end{array}$ & $\begin{array}{c}200 \text { mg Pembrolizumab } \\
\text { intravenous over } 30 \mathrm{~min} \\
\text { every } \\
3 \text { weeks for } \\
\text { maximum } 2 \text { years }\end{array}$ & $\begin{array}{l}\text { Pembrolizumab used } \\
\text { as monotherapy for } \\
\text { positive PD-L1 } \\
\text { mTNBC not previously } \\
\text { treated showed a low } \\
\text { incident rate for serious } \\
\text { adverse events } \\
\text { (grade 3, 9.5\%). } \\
\text { In addition, durable } \\
\text { and effective antitumor } \\
\text { activity was shown as } \\
\text { the ORR was } 21.4 \% \\
(95 \% \mathrm{CI}=13.9-31.4)\end{array}$ \\
\hline 10 & $\begin{array}{l}\text { Connolly } \\
\text { et al. (54) }\end{array}$ & 2017 & $\begin{array}{l}\text { Single arm, } \\
\text { multicenter, } \\
\text { phase II study }\end{array}$ & $\begin{array}{l}40 \text { female patients including } \\
13 \text { with TNBC and } 27 \text { with } \\
\text { hormone resistant breast }\end{array}$ & $\begin{array}{c}\text { AZA and entinostat } \\
(7 \text { mg orally, days } 3 \text { and } 10) \\
\text { every } 28 \text { days (cycle) }\end{array}$ & $\begin{array}{l}\text { There was no response } \\
\text { to treatment provided } \\
\text { in women with TNBC. }\end{array}$ \\
\hline 11 & $\begin{array}{c}\mathrm{Kim} \\
\text { et al. }(60)\end{array}$ & 2017 & $\begin{array}{l}\text { Randomised, } \\
\text { double-blind, } \\
\text { placebo-controlled, } \\
\text { phase I trial }\end{array}$ & $\begin{array}{l}\text { cancer } 124 \text { women } \\
\text { aged more than } 18 \\
\text { years old suffering } \\
\text { from metastatic or } \\
\text { locally advanced } \\
\text { TNBC with ECOG } \\
\text { performance status }<2\end{array}$ & $\begin{array}{l}\text { IV paclitaxel (day } 1,8,15) \\
\text { plus ipatasertib } 400 \mathrm{mg} \\
\text { or placebo daily for days } \\
1 \text { to } 21 \text { every } \\
\text { cycle ( } 28 \text { days) }\end{array}$ & $\begin{array}{l}\text { The period of progression } \\
\text { free survival was longer } \\
\text { in patients treated } \\
\text { with ipatasertib than } \\
\text { those treated with placebo. } \\
\text { ([HR] } 0.60 ; 95 \% \mathrm{CI}= \\
\quad 37-98 \% ; p=0.037)\end{array}$ \\
\hline 12 & $\begin{array}{l}\text { Basho } \\
\text { et al. }(61)\end{array}$ & 2017 & $\begin{array}{l}\text { Phase I } \\
\text { study }\end{array}$ & $\begin{array}{l}52 \text { female patients with } \\
\text { mTNBC aging } \\
\text { between } 37-79 \text { years old }\end{array}$ & $\begin{array}{l}\text { On the first day of every } \\
\text { cycle ( } 21 \text { days of duration) } \\
\text { intravenous of both } \\
\text { bevacizumab and liposomal } \\
\text { doxorubicin combined with } \\
\text { daily oral everolimus (DAE) } \\
\text { or weekly intravenous } \\
\text { temsirolimus (DAT) }\end{array}$ & $\begin{array}{l}\text { The patients showed a } \\
\text { CBR of } 40 \%(95 \% \mathrm{CI}= \\
27-55 \%) \text { and an ORR of } \\
21 \%(\text { complete response } \\
\text { [CR]=4 [8\%]; partial } \\
\text { response [PR]=7 } \\
\text { [13\%] }(95 \% \mathrm{CI}=11-35 \%) \text {. } \\
\text { PI3K pathway aberration } \\
\text { is related to improved } \\
\text { objective response rate } \\
(31 \% \text { vs. } 0 \% ; p=0.04)\end{array}$ \\
\hline 13 & $\begin{array}{l}\text { Jovanovic } \\
\text { et al. }(62)\end{array}$ & 2017 & $\begin{array}{l}\text { Multicenter, } \\
\text { double-blinded, } \\
\text { randomized, } \\
\text { placebo-controlled, } \\
\text { phase II clinical trial }\end{array}$ & $\begin{array}{l}145 \text { patients }>18 \text { years old, } \\
\text { with clinical stage } 2 \text { or } 3 \\
\text { of TNBC and ECOG } \\
\text { performance status }<2 \\
\text { divided in a placebo and } \\
\text { in an everolimus } \\
\text { administrated group }\end{array}$ & $\begin{array}{l}\text { Cisplatin weekly for } 12 \\
\text { weeks, paclitaxel weekly } \\
\text { for } 11 \text { weeks (administration } \\
\text { started } 1 \text { week after } \\
\text { cisplatin initiation) } \\
\text { and everolimus } \\
5 \mathrm{mg} \text { orally daily } \\
\text { or placebo orally } \\
\text { daily for } 12 \text { weeks }\end{array}$ & $\begin{array}{l}\text { The simultaneous use of } \\
\text { cisplatin/paclitaxel and } \\
\text { everolimus failed to } \\
\text { improve PCR compared } \\
\text { to the placebo group } \\
\text { (36\% compared to } 49 \%) \\
\text { and; led to increased } \\
\text { adverse events }\end{array}$ \\
\hline 14 & $\begin{array}{l}\text { Traina } \\
\text { et al. }(65)\end{array}$ & 2018 & $\begin{array}{c}\text { Prospective } \\
\text { phase II study }\end{array}$ & $\begin{array}{c}118 \text { patients (78 evaluated) } \\
\text { with AR+ TNBC locally } \\
\text { advanced or metastatic }\end{array}$ & $\begin{array}{l}160 \mathrm{mg} \text { of enzalutamide } \\
\text { once daily until } \\
\text { disease progression }\end{array}$ & $\begin{array}{l}\text { There was significant } \\
\text { clinical benefit with the } \\
\text { use of enzalutamide as } \\
\text { CBR was } 25 \% \text { ( } 95 \% \text { CI= } \\
17-33 \%) \text { and its adverse } \\
\text { events were well tolerated }\end{array}$ \\
\hline 15 & $\begin{array}{l}\text { Bonnefoi } \\
\text { et al. (66) }\end{array}$ & 2016 & $\begin{array}{l}\text { Single-arm open- } \\
\text { label phase II study }\end{array}$ & $\begin{array}{c}34 \text { patients with AR+TNBC } \\
\text { locally advanced } \\
\text { or metastatic }\end{array}$ & $\begin{array}{l}1000 \mathrm{mg} \text { of AA (four } \\
\text { tablets of } 250 \mathrm{mg} \text {, } \\
\text { daily) and prednisone } \\
5 \mathrm{mg} \text { twice every day }\end{array}$ & $\begin{array}{l}\text { The administration of } \\
\text { abiraterone acetate } \\
\text { demonstrated a } 20 \% \\
\text { clinical benefit rate after } \\
6 \text { months of treatment } \\
(6 / 30 ; 95 \% \text { CI }=7.7-38.6 \%)\end{array}$ \\
\hline
\end{tabular}


Table I. Continued

\begin{tabular}{|c|c|c|c|c|c|c|}
\hline Entry & Author & Year & Study & Patients & Therapy & Conclusion \\
\hline 16 & $\begin{array}{l}\text { Llombart- } \\
\text { Cussac } \\
\text { et al. }(73)\end{array}$ & 2015 & $\begin{array}{l}\text { Multicenter, } \\
\text { randomized open- } \\
\text { label phase II study. }\end{array}$ & $\begin{array}{l}141 \text { patients with TNBC } \\
\text { Stage II-IIIA }\end{array}$ & $\begin{array}{c}3 \text { groups: } \\
\text { a. PTX } \\
\text { b. Paclitaxel plus } \\
\text { iniparib weekly PWI } \\
\text { c. PTI }\end{array}$ & $\begin{array}{c}\text { PCR was similar } \\
\text { in the three groups PTX: } \\
10(21 \%) \text { patients, PWI: } \\
10(22 \%) \text { patients, and } \\
\text { PTI: } 9(19 \%) \text { patients. } \\
\text { The addition of iniparib } \\
\text { increased neither } \\
\text { antitumor activity } \\
\text { nor toxicity. }\end{array}$ \\
\hline 17 & $\begin{array}{l}\text { Kummar } \\
\text { et al. }(74)\end{array}$ & 2016 & $\begin{array}{l}\text { Multicenter, } \\
\text { open-label, } \\
\text { randomized } \\
\text { phase II study }\end{array}$ & $\begin{array}{l}45 \text { patients with } \\
\text { mTNBC }\end{array}$ & $\begin{array}{l}\text { Cyclophosphamide alone } \\
\text { or co-administered with } \\
\text { veliparib at } 60 \mathrm{mg} \text { per day } \\
\text { in } 21 \text {-day cycles }\end{array}$ & $\begin{array}{l}\text { No improvement was } \\
\text { observed to the response } \\
\text { rate after the combination } \\
\text { of both drugs compared to } \\
\text { cyclophosphamide alone }\end{array}$ \\
\hline 18 & $\begin{array}{l}\text { Tolaney } \\
\text { et al. (83) }\end{array}$ & 2016 & $\begin{array}{l}\text { Single-arm, } \\
\text { two-stage } \\
\text { phase II study }\end{array}$ & $\begin{array}{c}35 \text { women of median age } \\
50 \text { years with } \\
\text { mTNBC and ECOG } \\
\text { performance status }<3\end{array}$ & $\begin{array}{l}\text { Cabozantinib } 60 \mathrm{mg} \text { once } \\
\text { per day for } 3 \text { weeks } \\
\text { in each cycle }\end{array}$ & $\begin{array}{l}\text { Cabozantinib demonstrated } \\
\text { a clinical benefit rate } \\
\text { of } 34 \% \text { after } 15 \text { weeks } \\
\text { of treatment } \\
(95 \% \text { CI }=19-52 \%) \text { although } \\
\text { only } 3 \text { patients showed } \\
\text { partial response (ORR, } 9 \%) \\
(95 \% \mathrm{CI}=2-26)\end{array}$ \\
\hline
\end{tabular}

PTX: Paclitaxel alone; PWI: paclitaxel plus iniparib weekly; PTI: paclitaxel plus iniparib twice a week; AA: abiraterone Acetate; IDFS: invasive disease-free survival; mTNBC: metastatic triple-negative breast cancer; TNBC: triple-negative breast cancer; ORR: objective response rate; PFS: progression-free survival; ECOG: Eastern Cooperative Oncology Group; IV: intravenous; CI: confidence interval; AZA: 5-azacitidine; CR: complete response; PR: partial response; CBR: clinical benefit rate; PCR: pathologic complete response; AR: androgen receptor.

In 2016, Nanda et al., conducted a multicohort, nonrandomized, phase Ib study, in which 32 women with positive PD-L1 TNBC, aging between 29 to 72 years old, were enrolled (Table I, Entry 6). Intravenous administration of pembrolizumab at a dose of $10 \mathrm{mg} / \mathrm{kg}$ every 2 weeks was found to be clinically efficacious against cancer cells and to have a tolerable safety profile with limited toxicity (47).

One year later, a phase 1 trial evaluated the clinical response of 168 patients with metastatic breast cancer, including 58 patients with TNBC (Table I, Entry 7). Patients received pembrolizumab at a dose of $10 \mathrm{mg} / \mathrm{kg}$ every 2 weeks. It was pointed out that, especially in the TNBC population there was a greater antitumor activity without serious adverse events (48).

Next year, a group of 170 female individuals between 28 to 85 years old with metastatic TNBC, who had already received previous chemotherapy treatment, received $200 \mathrm{mg}$ of pembrolizumab intravenously over 30 min every 3 weeks for maximum 2 years (Table I, Entry 8). Patients treated with pembrolizumab, showed significant clinical response with acceptable adverse events (49).

In addition, another phase II study aimed to examine the efficacy and the safety profile of pembrolizumab, as a first- line treatment in 84 individuals diagnosed with PD-L1 positive mTNBC (Table I, Entry 9). According to Adams's study, there was significant evidence that pembrolizumab led to a low incident rate of severe adverse events, with durable and effective antitumor activity (50).

Histone deacetylase inhibitors. Both histone acetylation and deacetylation demonstrate a great effect on chromatin structure and remodeling. According to functional criteria, histone deacetylases (HDAC) can be classified in four classes, which can be divided into two groups, the NADdependent class III and the $\mathrm{Zn}^{2+}$-dependent classes of I, II and IV. These classes include a) hydroxamates, b) benzamides c) cyclic peptides and d) aliphatic acids (51). HDAC inhibitors (HDACI) affect a wider spectrum of cellular functions in cancer cells, such as cell proliferation, cell death, gene expression and cell migration (52). In addition, anti-angiogenesis and prevention of glycose metabolism are additional mechanisms of action against cancer cells (53). Importantly, normal cells seem to be relatively resistant to HDACI and be less affected by their actions, providing an opportunity to maximize results against cancer cells and minimize toxicity on healthy ones $(52,53)$. 
In 2016, a multicenter phase II study tested the objective response rate of entinostat and 5-azacitidine (AZA) in 40 patients with advanced breast cancer, including 13 with TNBC (Table 1, Entry 10). The clinical results showed that there was no response to treatment provided in women with TNBC (54).

PI3K/AKT/mTOR pathway inhibitors. The aberrations in the $\mathrm{PI} 3 \mathrm{~K} / \mathrm{AKT} / \mathrm{mTOR}$ pathway are considered to be common in various subtypes of breast cancer including TNBC (55). In TNBC, overexpression of regulators, such as epidermal growth factor receptor (EGFR), the loss of function of phosphatase and tension homolog (PTEN) or the presence of mutations, which activate the PI3K subunit a, can trigger oncogenic activation of this pathway (56-58). Downstream of PI3K is AKT, which is inhibited by ipatasertib (59). In 2017, Kim et al., conducted a phase II trial, in which 124 women suffering from metastatic or locally advanced TNBC with ECOG performance status $<2$ participated (Table I, Entry 11). Patients were randomized to paclitaxel plus 400 $\mathrm{mg}$ oral ipatasertib or placebo on days 1 and 21 on each cycle (28-days). The period of progression-free survival was longer in patients treated with ipatasertib, than in those treated with placebo. Furthermore, the risk of adverse events grade $\geq 3$ was slightly higher in patients receiving ipatasertib compared to those receiving placebo (60).

Concerning the mTOR inhibitors, in 2016, 52 female patients with metaplastic TNBC participated in a phase I study (Table I, Entry 12). On the first day of every cycle (of 21 days duration) both bevacizumab and liposomal doxorubicin, combined with daily oral everolimus (DAE) or weekly intravenous temsirolimus (DAT), were administered to participants. Both combinations showed remarkable activity against metaplastic TNBC. Additionally, PI3K pathway aberrations were related to improved objective response rate (61).

Next year, investigators tested the use of Cisplatin weekly for 12 weeks, paclitaxel weekly for 11 weeks (administration started 1 week after cisplatin initiation) and everolimus $5 \mathrm{mg}$ orally daily or placebo orally daily for 12 weeks in 145 patients with Stage II/III TNBC and ECOG performance status <2 (Table I, Entry 13). The results revealed that the triple combination therapy, compared to cisplatin/paclitaxel, failed to improve the clinical outcome of patients. In addition, more adverse events occurred (62).

Androgen-targeted therapy. The androgen receptor (AR) is found in both malignant and normal breast tissue and its prevalence varies according to the histological subtype of breast cancer. Approximately 10-15\% of TNBC expressing AR show a more benign course $(63,64)$. In 2018, Traina et al. tested 175 individuals with AR positive, locally advanced or metastatic TNBC. Patients received $160 \mathrm{mg}$ of enzalutamide once daily until disease progression (Table I, Entry 14). The outcome of the prospective phase II study indicated that there was a significant clinical benefit from the use of enzalatumide (65).

Next year, a group of scientists evaluated the efficacy of $1,000 \mathrm{mg}$ of Abiraterone Acetate (four tablets of $250 \mathrm{mg}$, daily) and $5 \mathrm{mg}$ prednisone twice every day in 34 patients with AR positive, locally advanced or metastatic triplenegative breast cancer (Table I, Entry 15). They showed that administration of abiraterone acetate demonstrated significant clinical benefit after 6 months of treatment. Additionally, the majority of the adverse events were characterized as grade 1 and 2 (66).

Poly-ADP ribose polymerase (PARP) inhibitors. Poly-ADPribose synthesis consists one of the primary responses to DNA strand breaks. PARP1, as a stable element of chromatin, accelerates DNA repair via various mechanisms, such as attraction of other repairing proteins and binding to DNA breaks (67-71). PARP inhibitors induce apoptosis, by causing accumulation of damaged cellular DNA. Thus, the inhibition of PARP-1 can cease the procedure or repairment in a single-stranded intermediate state $(69,70,72)$.

In 2015, 141 patients with TNBC Stage II-IIIa were evaluated in a phase II study (Table I, Entry 16). The patients were divided into three groups depending on the neoadjuvant regimen received. They were randomized to receive paclitaxel alone (PTX), paclitaxel plus iniparib weekly (PWI), and paclitaxel plus iniparib twice a week (PTI). The investigators demonstrated that pathologic complete response was similar in the three groups and the addition of iniparib increase neither antitumor activity nor toxicity (73).

One year later, a group of 45 patients with metastatic TNBC were enrolled in a randomized phase II study (Table I, Entry 17). They randomly received cyclophosphamide alone or co-administered with veliparib at $60 \mathrm{mg}$ per day in 21-day cycles. According to the results, no improvement was observed to the response rate, after the combination of both drugs, compared to cyclophosphamide alone (74).

Tyrosine kinase inhibitors. MET is a tyrosine kinase receptor, which binds to its ligand hepatocyte growth factor (HGF) (75). Its activation leads to proliferation, survival and invasion of cancer cells and is associated with poor clinical outcome (76-81). Cabozantinib consists an inhibitor of various tyrosine kinases, such as MET and the vascular endothelial growth factor receptor 2 (VEGFR2) (82).

In 2016, Tolaney et al., conducted a phase II study, in which they tested 35 women of median age 50 years with metastatic TNBC (Table I, Entry 18). Cabozantinib $60 \mathrm{mg}$ once per day for 3 weeks in each cycle was administered to participants. Via analysis of blood biomarkers during treatment, they showed that cabozantinib leads to immune 
system activation and prevents angiogenesis. Thus, cabozantinib showed clinical benefit without adverse events grade $>3$ even though it did not reach the objective response rate in pre-treated metastatic TNBC patients (83).

\section{Conclusion}

TNBC is characterized by great metastatic ability and is associated with poor clinical result. Patients with the TNBC do not benefit from hormonal treatment or treatment with anti-HER2 antibodies (trastuzumab), since their tumors do not express the ER, PR, and HER2 receptors. Surgery, radiation therapy, and chemotherapy, used alone or in various combinations, are currently the primary reliable therapeutic options for patients with TNBC. Thus, it is necessary to conduct studies with specifically selected patient populations, as the TNBC is so heterogeneous. As it is shown in this review, numerous new therapeutic targets have emerged, such as tyrosine kinase inhibitors, antiandrogens, poly ADP-ribose polymerase-1 (PARP-1) inhibitors, antiangiogenic factors, immune checkpoints and HDACI. In addition, the PI3K/AKT/mTOR pathway is regarded as another evolving field, concerning treatment of TNBC.

In conclusion, as new opportunities emerge from the development of all these potential new targeted therapies against TNBC, more clinical trials should be conducted in order to examine the toxicity profile and the efficacy of the new agents.

\section{Conflicts of Interest}

All the Authors declare that there is no conflict of interest regarding this study.

\section{Authors' Contributions}

$\mathrm{CD}$ and $\mathrm{NG}$ designed the study. $\mathrm{CD}, \mathrm{AG}, \mathrm{KN}$ and $\mathrm{NG}$ wrote the article. $\mathrm{CD}, \mathrm{AG}, \mathrm{KN}, \mathrm{MV}, \mathrm{ED}, \mathrm{AP}, \mathrm{PF}$ and $\mathrm{NG}$ collected the data. AN, DM, NN and KK offered scientific advice. DD, EAA and NG revised the manuscript. NG was the supervisor.

\section{References}

1 Adkins FC, Gonzalez-Angulo AM, Lei X, Hernandez-Aya LF, Mittendorf EA, Litton JK, Wagner J, Hunt KK, Woodward WA and Meric-Bernstam F: Triple-negative breast cancer is not a contraindication for breast conservation. Ann Surg Oncol 18(11): 3164-3173, 2011. PMID: 21947595. DOI: 10.1245/s10434-0111920-Z

2 Brenton JD, Carey LA, Ahmed AA and Caldas C: Molecular classification and molecular forecasting of breast cancer: ready for clinical application? J Clin Oncol 23(29): 7350-7360, 2005. PMID: 16145060. DOI: 10.1200/JCO.2005.03.3845

3 American Cancer Society. Cancer Facts and Figures 2017. Atlanta, GA: American Cancer Society; 2017.
4 Dent R, Trudeau M, Pritchard KI, Hanna WM, Kahn HK, Sawka CA, Lickley LA, Rawlinson E, Sun P and Narod SA: Triplenegative breast cancer: clinical features and patterns of recurrence. Clin Cancer Res 13(15 Pt 1): 4429-4434, 2007. PMID: 17671126. DOI: 10.1158/1078-0432.CCR-06-3045

5 Bauer KR, Brown M, Cress RD, Parise CA and Caggiano V: Descriptive analysis of estrogen receptor (ER)-negative, progesterone receptor (PR)-negative, and HER2-negative invasive breast cancer, the so-called triple-negative phenotype: a population-based study from the California cancer registry. Cancer 109(9): 1721-1728, 2007. PMID: 17387718. DOI: 10.1002/cncr.22618

6 Loibl S, Muller BM, von Minckwitz G, Schwabe M, Roller M, Darb-Esfahani S, Ataseven B, du Bois A, Fissler-Eckhoff A, Gerber B, Kulmer U, Alles JU, Mehta K and Denkert C: Androgen receptor expression in primary breast cancer and its predictive and prognostic value in patients treated with neoadjuvant chemotherapy. Breast Cancer Res Treat 130(2): 477487, 2011. PMID: 21837479. DOI: 10.1007/s10549-011-1715-8

7 Lehmann BD, Bauer JA, Chen X, Sanders ME, Chakravarthy AB, Shyr Y and Pietenpol JA: Identification of human triple negative breast cancer subtypes and preclinical models for selection of targeted therapies. J Clin Invest 121(7): 2750-2767, 2011. PMID: 21633166. DOI: 10.1172/JCI45014

8 Smid M, Wang Y, Zhang Y, Sieuwerts AM, Yu J, Klijn JG, Foekens JA and Martens JW: Subtypes of breast cancer show preferential site of relapse. Cancer Res 68(9): 3108-3114, 2008. PMID: 18451135. DOI: 10.1158/0008-5472.CAN-07-5644

9 Diaz LK, Cryns VL, Symmans WF and Sneige N: Triple negative breast carcinoma and the basal phenotype: from expression profiling to clinical practice. Adv Anat Pathol 14(6): 419-430, 2007. PMID: 18049131. DOI: 10.1097/PAP.0b0 $13 \mathrm{e} 3181594733$

10 Marmé $\mathrm{F}$ and Schneeweiss A: Targeted therapies in triplenegative breast cancer. Breast Care (Basel) 10(3): 159-166, 2015. PMID: 26557820. DOI: 10.1159/000433622

11 von Minckwitz G, Untch M, Nüesch E, Loibl S, Kaufmann M, Kümmel S, Fasching PA, Eiermann W, Blohmer JU, Costa SD, Mehta K, Hilfrich J, Jackisch C, Gerber B, du Bois A, Huober J, Hanusch C, Konecny G, Fett W, Stickeler E, Harbeck N, Müller V and Jüni P: Impact of treatment characteristics on response of different breast cancer phenotypes: pooled analysis of the German neo-adjuvant chemotherapy trials. Breast Cancer Res Treat 125(1): 145-156, 2011. PMID: 21042932. DOI: 10.1007/s10549-010-1228-x

12 Gluz O, Liedtke C, Gottschalk N, Pusztai L, Nitz U and Harbeck $\mathrm{N}$ : Triple-negative breast cancer current status and future directions. Ann Oncol 20(12): 1913-1927, 2009. PMID: 19901010. DOI: 10.1093/annonc/mdp492

13 Bosch A, Eroles P, Zaragoza R, Viña JR and Lluch A: Triplenegative breast cancer: molecular features, pathogenesis, treatment and current lines of research. Cancer Treat Rev 36(3): 206-215, 2010. PMID: 20060649. DOI: 10.1016/j.ctrv. 2009.12.002

14 de Ruijter TC, Veeck J, de Hoon JP, van Engeland M and TjanHeijnen VC: Characteristics of triple-negative breast cancer. J Cancer Res Clin Oncol 137(2): 183-192, 2011. PMID: 21069385. DOI: 10.1007/s00432-010-0957-x

15 Perou CM, Sorlie T, Eisen MB, van de Rijn M, Jeffrey SS, Rees CA, Pollack JR, Ross DT, Johnsen H, Akslen LA, Fluge O, 
Pergamenschikov A, Williams C, Zhu SX, Lønning PE, Børresen-Dale AL, Brown PO and Botstein D: Molecular portraits of human breast tumours. Nature 406(6797): 747-752, 2000. PMID: 10963602. DOI: 10.1038/35021093

16 Rodriguez-Pinilla SM, Sarrio D, Honrado E, Hardisson D, Calero F, Benitez J, Palacios J: Prognostic significance of basallike phenotype and fascin expression in node-negative invasive breast carcinomas. Clin Cancer Res 12(5): 1533-1539, 2006 PMID: 16533778. DOI: 10.1158/1078-0432.CCR-05-2281

17 Collignon J, Lousberg L, Schroeder H and Jerusalem G: Triplenegative breast cancer: treatment challenges and solutions. Breast Cancer (Dove Med Press) 8: 93-107, 2016. PMID: 27284266. DOI: 10.2147/BCTT.S69488

18 Heitz F, Harter P, Lueck HJ, Fissler-Eckhoff A, Lorenz-Salehi F, Scheil-Bertram S, Traut A and du Bois A: Triple-negative and HER2-overexpressing breast cancers exhibit an elevated risk and an earlier occurrence of cerebral metastases. Eur J Cancer 45(16): 2792-2798, 2009. PMID: 19643597. DOI: 10.1016/ j.ejca.2009.06.027

19 Lin NU, Claus E, Sohl J, Razzak AR, Arnaout A and Winer EP: Sites of distant recurrence and clinical outcomes in patients with metastatic triple negative breast cancer: High incidence of central nervous system metastases. Cancer 113(10): 2638-2645, 2008. PMID: 18833576. DOI: 10.1002/cncr.23930

20 Liedtke C, Mazouni C, Hess KR, André F, Tordai A, Mejia JA, Symmans WF, Gonzalez-Angulo AM, Hennessy B, Green M, Cristofanilli M, Hortobagyi GN and Pusztai L: Response to neoadjuvant therapy and long-term survival in patients with triple-negative breast cancer. J Clin Oncol 26(8): 1275-1281, 2008. PMID: 18250347. DOI: 10.1200/JCO.2007.14.4147

21 Jatoi I, Anderson WF, Jeong JH and Redmond CK: Breast cancer adjuvant therapy: Time to consider its time-dependent effects. J Clin Oncol 29(17): 2301-2304, 2011. PMID: 21555693. DOI: 10.1200/JCO.2010.32.3550

22 Cortazar P, Zhang L, Untch M, Mehta K, Costantino JP, Wolmark N, Bonnefoi H, Cameron D, Gianni L, Valagussa P, Swain SM, Prowell T, Loibl S, Wickerham DL, Bogaerts J, Baselga J, Perou C, Blumenthal G, Blohmer J, Mamounas EP, Bergh J, Semiglazov V, Justice R, Eidtmann H, Paik S, Piccart M, Sridhara R, Fasching PA, Slaets L, Tang S, Gerber B, Geyer CE Jr, Pazdur R, Ditsch N, Rastogi P, Eiermann W and von Minckwitz G: Pathological complete response and long-term clinical benefit in breast cancer: The CTNeoBC pooled analysis. Lancet 384(9938): 164-172, 2014. PMID: 24529560. DOI 10.1016/S0140-6736(13)62422-8

23 Fedele P, Orlando L and Cinieri S: Targeting triple negative breast cancer with histone deacetylase inhibitors. Expert Opin Investig Drugs 26(11): 1199-1206, 2017. PMID: 28952409. DOI: $10.1080 / 13543784.2017 .1386172$

24 Saloustros E, Nikolaou M, Kalbakis K, Polyzos A, Christofillakis C, Kentepozidis N, Pistamaltzian N, Kourousis C, Vamvakas L, Georgoulias V and Mavroudis D: Weekly paclitaxel and carboplatin plus bevacizumab as first-line treatment of metastatic triple-negative breast cancer. A multicenter phase II trial by the Hellenic oncology research group. Clin Breast Cancer 18(1): 88-94, 2018. PMID: 29153775. DOI: $10.1016 /$ j.clbc.2017.10.013

25 O'Shaughnessy J, Osborne C, Pippen JE, Yoffe M, Patt D, Rocha C, Koo IC, Sherman BM and Bradley C: Iniparib plus chemotherapy in metastatic triple-negative breast cancer. $\mathrm{N}$ Engl
J Med 364(3): 205-214, 2011. PMID: 21208101. DOI: 10.1056/NEJMoa1011418

26 O'Shaughnessy J, Schwartzberg LS, Danso MA, Miller KD, Rugo HS, Neubauer M, Robert N, Hellerstedt B, Saleh M, Richards P, Specht JM, Yardley DA, Carlson RW, Finn RS, Charpentier E, Garcia-Ribas I and Winer EP: Phase III study of iniparib plus gemcitabine and carboplatin versus gemcitabine and carboplatin in patients with metastatic triple-negative breast cancer. J Clin Oncol 32(34): 3840-3847, 2014. PMID: 25349301. DOI: $10.1200 / J C O .2014 .55 .2984$

27 Miles DW, Diéras V, Cortés J, Duenne AA, Yi J and O'Shaughnessy J: First-line bevacizumab in combination with chemotherapy for HER2-negative metastatic breast cancer: pooled and subgroup analyses of data from 2447 patients. Ann Oncol 24(11): 2773-2780, 2013. PMID: 23894038. DOI: 10.1093/annonc/mdt276

28 Miller K, Wang M, Gralow J, Dickler M, Cobleigh M, Perez EA, Shenkier T, Cella D and Davidson NE: Paclitaxel plus bevacizumab versus paclitaxel alone for metastatic breast cancer. N Engl J Med 357(26): 2666-2676, 2007. PMID: 18160686. DOI: $10.1056 /$ NEJMoa072113

29 Miles DW, Chan A, Dirix LY, Cortés J, Pivot X, Tomczak P, Delozier T, Sohn JH, Provencher L, Puglisi F, Harbeck N, Steger GG, Schneeweiss A, Wardley AM, Chlistalla A and Romieu G: Phase III study of bevacizumab plus docetaxel compared with placebo plus docetaxel for the first-line treatment of human epidermal growth factor receptor 2-negative metastatic breast cancer. J Clin Oncol 28(20): 3239-3247, 2010. PMID: 20498403. DOI: 10.1200/JCO.2008.21.6457

30 Cameron D, Brown J, Dent R, Jackisch C, Mackey J, Pivot X, Steger GG, Suter TM, Toi M, Parmar M, Laeufle R, Im YH, Romieu G, Harvey V, Lipatov O, Pienkowski T, Cottu P, Chan A, Im SA, Hall PS, Bubuteishvili-Pacaud L, Henschel V, Deurloo RJ, Pallaud C and Bell R: Adjuvant bevacizumabcontaining therapy in triple-negative breast cancer (BEATRICE): primary results of a randomised, phase 3 trial. Lancet Oncol 14(10): 933-942, 2013. PMID: 23932548. DOI: 10.1016/S14702045(13)70335-8

31 Curigliano G, Pivot X, Cortés J, Elias A, Cesari R, Khosravan R, Collier M, Huang X, Cataruozolo PE, Kern KA and Goldhirsch A: Randomized phase II study of sunitinib versus standard of care for patients with previously treated advanced triple-negative breast cancer. Breast 22(5): 650-656, 2013. PMID: 23958375. DOI: 10.1016/j.breast.2013.07.037

32 Gradishar WJ, Kaklamani V, Sahoo TP, Lokanatha D, Raina V, Bondarde S, Jain M, Ro SK, Lokker NA and Schwartzberg L: A double-blind, randomised, placebo-controlled, phase $2 \mathrm{~b}$ study evaluating sorafenib in combination with paclitaxel as a firstline therapy in patients with HER2-negative advanced breast cancer. Eur J Cancer 49(2): 312-322, 2013. PMID: 22954665. DOI: $10.1016 /$ j.ejca.2012.08.005

33 Gucalp A, Tolaney S, Isakoff SJ, Ingle JN, Liu MC, Carey LA, Blackwell K, Rugo H, Nabell L, Forero A, Stearns V, Doane AS, Danso M, Moynahan ME, Momen LF, Gonzalez JM, Akhtar A, Giri DD, Patil S, Feigin KN, Hudis CA, Traina TA and Translational Breast Cancer Research Consortium (TBCRC 011): Trial of bicalutamide in patients with androgen receptorpositive, estrogen receptor-negative metastatic breast cancer. Clin Cancer Res 19(19): 5505-5512, 2013. PMID: 23965901. DOI: $10.1158 / 1078-0432 . C C R-12-3327$ 
34 Costa RBL, Han SH and Gradishar WJ: Targeting the $\mathrm{PI} 3 \mathrm{~K} / \mathrm{AKT} / \mathrm{mTOR}$ pathway in triple-negative breast cancer: a review. Breast Cancer Res Treat 169(3): 397-406, 2018. PMID: 29417298. DOI: 10.1007/s10549-018-4697-y

35 Andre F, Job B, Dessen P, Tordai A, Michiels S, Liedtke C, Richon C, Yan K, Wang B, Vassal G, Delaloge S, Hortobagyi GN, Symmans WF, Lazar V and Pusztai L: Molecular characterization of breast cancer with high-resolution oligonucleotide comparative genomic hybridization array. Clin Cancer Res 15(2): 441-451, 2009. PMID: 19147748. DOI: 10.1158/1078-0432.CCR-08-1791

36 Linderholm BK, Hellborg H, Johansson U, Elmberger G, Skoog L, Lehtiö J and Lewensohn R: Significantly higher levels of vascular endothelial growth factor (VEGF) and shorter survival times for patients with primary operable triple-negative breast cancer. Ann Oncol 20(10): 1639-1646, 2009. PMID: 19549711. DOI: $10.1093 /$ annonc/mdp062

37 Hervé MA, Buteau-Lozano H, Vassy R, Bieche I, Velasco G, Pla M, Perret G, Mourah S and Perrot-Applanat M: Overexpression of vascular endothelial growth factor 189 in breast cancer cells leads to delayed tumor uptake with dilated intratumoral vessels. Am J Pathol 172(1): 167-178, 2008. PMID: 18079435. DOI: 10.2353/ajpath.2008.070181

38 Linderholm BK, Lindahl T, Holmberg L, Klaar S, Lennerstrand $\mathrm{J}$, Henriksson R and Bergh J: The expression of vascular endothelial growth factor correlates with mutant p53 and poor prognosis in human breast cancer. Cancer Res 61(5): 2256-2260, 2001. PMID: 11280795.

39 Ferrero JM, Hardy-Bessard AC, Capitain O, Lortholary A, Salles B, Follana P, Herve R, Deblock M, Dauba J, Atlassi M and Largillier R: Weekly paclitaxel, capecitabine, and bevacizumab with maintenance capecitabine and bevacizumab as first-line therapy for triple-negative, metastatic, or locally advanced breast cancer: Results from the GINECO A-TaXel phase 2 study. Cancer 122(20): 3119-3126, 2016. PMID: 27412268. DOI: 10.1002/cncr.30170

40 Bell R, Brown J, Parmar M, Toi M, Suter T, Steger GG, Pivot X, Mackey J, Jackisch C, Dent R, Hall P, Xu N, Morales L, Provencher L, Hegg R, Vanlemmens L, Kirsch A, Schneeweiss A, Masuda N, Overkamp F and Cameron D: Final efficacy and updated safety results of the randomized phase III BEATRICE trial evaluating adjuvant bevacizumab-containing therapy in triple-negative early breast cancer. Ann Oncol 28(4): 754-760, 2017. PMID: 27993816. DOI: 10.1093/annonc/mdw665

41 Symonds L, Linden H, Gadi V, Korde L, Rodler E, Gralow J, Redman M, Baker K, Wu V, Jenkins I, Kurland B, Garrison M, Smith J, Anderson J, Van Haelst C, Seattle Cancer Care Alliance Network Investigators and Specht J: Combined targeted therapies for first-line treatment of metastatic triple negative breast cancer-A phase II trial of weekly nab-paclitaxel and bevacizumab followed by maintenance targeted therapy with bevacizumab and erlotinib. Clin Breast Cancer 19(2): 283-296, 2019. PMID: 30737173. DOI: 10.1016/j.clbc.2018.12.008

42 Mery B, Rowinski E, Vallard A, Jacquin JP, Simoens X, Magné $\mathrm{N}$ and Doucey P: Advocacy for a new oncology research paradigm: The model of bevacizumab in triple-negative breast cancer in a French cohort study. Oncology 97(1): 1-6, 2019. PMID: 30939479. DOI: 10.1159/000499583

43 Kurozumi S, Inoue K, Matsumoto H, Fujii T, Horiguchi J, Oyama T, Kurosumi M and Shirabe K: Prognostic utility of tumor-infiltrating lymphocytes in residual tumor after neoadjuvant chemotherapy with trastuzumab for HER2-positive breast cancer. Sci Rep 9(1): 1583, 2019. PMID: 30733496. DOI: 10.1038/s41598-018-38272-1

44 Topalian SL, Taube JM, Anders RA and Pardoll DM: Mechanism-driven biomarkers to guide immune checkpoint blockade in cancer therapy. Nat Rev Cancer 16(5): 275-287, 2016. PMID: 27079802. DOI: 10.1038/nrc.2016.36

45 Dill EA, Gru AA, Atkins KA, Friedman LA, Moore ME, Bullock TN, Cross JV, Dillon PM and Mills AM: PD-L1 expression and intratumoral heterogeneity across breast cancer subtypes and stages: An assessment of 245 primary and 40 metastatic tumors. Am J Surg Pathol 41(3): 334-342, 2017. PMID: 28195880. DOI: 10.1097/PAS.0000000000000780

46 Solinas C, Gombos A, Latifyan S, Piccart-Gebhart M, Kok M and Buisseret L: Targeting immune checkpoints in breast cancer: An update of early results. ESMO Open 2(5): e000255, 2017. PMID: 29177095. DOI: 10.1136/esmoopen-2017-000255

47 Nanda R, Chow LQ, Dees EC, Berger R, Gupta S, Geva R, Pusztai L, Pathiraja K, Aktan G, Cheng JD, Karantza V and Buisseret L: Pembrolizumab in patients with advanced triplenegative breast cancer: Phase Ib KEYNOTE-012 Study. J Clin Oncol 34(21): 2460-2467, 2016. PMID: 27138582. DOI: 10.1200/JCO.2015.64.8931

48 Dirix LU, Takacs I, Jerusalem G, Nikolinakos P, Arkenau HT, Forero-Torres A, Boccia R, Lippman ME, Somer R, Smakal M, Emens LA, Hrinczenko B, Edenfield W, Gurtler J, von Heydebreck A, Grote HJ, Chin K and Hamilton EP: Avelumab, an anti-PD-L1 antibody, in patients with locally advanced or metastatic breast cancer: a phase 1b JAVELIN solid tumor study. Breast Cancer Res Treat 167(3): 671-686, 2017. PMID: 29063313. DOI: $10.1007 / \mathrm{s} 10549-017-4537-5$

49 Adams S, Schmid IP, Rugo HS, Winer EP, Loirat D, Awada A, Cescon DW, Iwata H, Campone M, Nanda R, Hui R, Curigliano G, Toppmeyer D, O'Shaughnessy J, Loi S, Paluch-Shimon S, Tan AR, Card D, Zhao J, Karantza V and Cortés J: Pembrolizumab monotherapy for previously treated metastatic triple-negative breast cancer: cohort A of the Phase II KEYNOTE-086 study. Ann Oncol 30(3): 397-404, 2019. PMID: 30475950. DOI: 10.1093/annonc/mdy517

50 Adams S, Loi S, Toppmeyer D, Cescon DW, De Laurentiis M, Nanda R, Winer EP, Mukai H, Tamura K, Armstrong A, Liu MC, Iwata H, Ryvo L, Wimberger P, Rugo HS, Tan AR, Jia L, Ding Y, Karantza V and Schmid P: Pembrolizumab monotherapy for previously untreated, $\mathrm{PD}$-L1-positive, metastatic triple-negative breast cancer: cohort B of the phase II KEYNOTE-086 study. Ann Oncol 30(3): 405-411, 2019. PMID: 30475947. DOI: 10.1093/annonc/mdy518

51 Garmpis N, Damaskos C, Garmpi A, Kalampokas E, Kalampokas T, Spartalis E, Daskalopoulou A, Valsami S, Kontos M, Nonni A, Kontzoglou K, Perrea D, Nikiteas $\mathrm{N}$ and Dimitroulis D: Histone deacetylases as new therapeutic targets in triple-negative breast cancer: Progress and promises. Cancer Genomics Proteomics 14(5): 299-313, 2017. PMID: 28870998. DOI: $10.21873 / \mathrm{cgp} .20041$

52 Damaskos C, Garmpis N, Valsami S, Kontos M, Spartalis E, Kalampokas T, Kalampokas E, Athanasiou A, Moris D, Daskalopoulou A, Davakis S, Tsourouflis G, Kontzoglou K, Perrea D, Nikiteas N and Dimitroulis D: Histone deacetylase inhibitors: An attractive therapeutic strategy against breast 
cancer. Anticancer Res 37(1): 35-46, 2017. PMID: 28011471 DOI: 10.21873 /anticanres.11286

53 Garmpi A, Garmpis N, Damaskos C, Valsami S, Spartalis E, Lavaris A, Patelis N, Margonis GA, Apostolou GK, Spartalis M, Andreatos N, Diamantis E, Tsivelekas K, Moschos MM, Nonni A, Tsourouflis G, Markatos K, Antoniou EA, Kontzoglou K, Nikiteas $\mathrm{N}$ and Dimitroulis D: Histone deacetylase inhibitors as a new anticancer option: How far can we go with expectations? J BUON 23(4): 846-861, 2018. PMID: 30358185.

54 Connolly RM, Li H, Jankowitz R C, Zhang Z, Rudek MA, Jeter SC, Slater SA, Powers P, Wolff AC, Fetting JH, Brufsky A, Piekarz R, Ahuja N, Laird PW, Shen H, Weisenberger DJ, Cope L, Herman JG, Somlo G, Garcia AA, Jones PA, Baylin SB, Davidson NE, Zahnow $\mathrm{CA}$ and Stearns V: Combination epigenetic therapy in advanced breast cancer with 5-azacitidine and entinostat: a phase II national cancer institute/stand up to cancer study. Clin Cancer Res 23(11): 2691-2701, 2017. PMID: 27979916. DOI: $10.1158 / 1078-0432 . C C R-16-1729$

55 Cancer Genome Atlas Network and Collaborators (357): Comprehensive molecular portraits of human breast tumours. Nature 490(7418): 61-70, 2012. PMID: 23000897. DOI: 10.1038 /nature 11412

56 Liu T, Yacoub R, Taliaferro-Smith LD, Sun SY, Graham TR, Dolan R, Lobo C, Tighiouart M, Yang L, Adams A and O'Regan $\mathrm{RM}$ : Combinatorial effects of lapatinib and rapamycin in triplenegative breast cancer cells. Mol Cancer Ther 10(8): 1460-1469, 2011. PMID: 21690228. DOI: 10.1158/1535-7163.MCT-10-0925

57 Cossu-Rocca P, Orru S, Muroni MR, Sanges F, Sotgiu G, Ena S, Pira G, Murgia L, Manca A, Uras MG, Sarobba MG, Urru S and De Miglio MR: Analysis of PIK3CA mutations and activation pathways in triple negative breast cancer. PLoS ONE 10(11): e0141763, 2015. PMID: 26540293. DOI: 10.1371/journal.pone. 0141763

58 Ooms LM, Binge LC, Davies EM, Rahman P, Conway JR, Gurung R, Ferguson DT, Papa A, Fedele CG, Vieusseux JL, Chai RC, Koentgen F, Price JT, Tiganis T, Timpson P, McLean CA and Mitchell CA: The inositol polyphosphate 5-phosphatase PIPP regulates AKT1-dependent breast cancer growth and metastasis. Cancer Cell 28(2): 155-169, 2015. PMID: 26267533. DOI: $10.1016 /$ j.ccell.2015.07.003

59 Lin J, Sampath D, Nannini MA, Lee BB, Degtyarev M, Oeh J, Savage H, Guan Z, Hong R, Kassees R, Lee LB, Risom T, Gross S, Liederer BM, Koeppen H, Skelton NJ, Wallin JJ, Belvin M, Punnoose E, Friedman LS and Lin K: Targeting activated Akt with GDC-0068, a novel selective Akt inhibitor that is efficacious in multiple tumor models. Clin Cancer Res 19(7): 1760-1772, 2013. PMID: 23287563. DOI: 10.1158/10780432.CCR-12-3072

60 Kim SB, Dent R, Im SA, Espié M, Blau S, Tan AR, Isakoff SJ, Oliveira M, Saura C, Wongchenko MJ, Kapp AV, Chan WY, Singel SM, Maslyar DJ and Baselga J; LOTUS investigators: Ipatasertib plus paclitaxel versus placebo plus paclitaxel as firstline therapy for metastatic triple-negative breast cancer (LOTUS): a multicentre, randomised, double-blind, placebocontrolled, phase 2 trial. Lancet Oncol 18(10): 1360-1372, 2017. PMID: 28800861. DOI: 10.1016/S1470-2045(17)30450-3

61 Basho RK, Gilcrease M, Murthy RK, Helgason T, Karp DD, Meric-Bernstam F, Hess KR, Herbrich SM, Valero V, Albarracin C, Litton JK, Chavez-MacGregor M, Ibrahim NK, Murray JL 3rd, Koenig KB, Hong D, Subbiah V, Kurzrock R, Janku F and
Moulder SL: Targeting the PI3K/AKT/mTOR pathway for the treatment of mesenchymal triple-negative breast cancer: Evidence from a phase 1 trial of mTOR inhibition in combination with liposomal doxorubicin and bevacizumab. JAMA Oncol 3(4): 509-515, 2017. PMID: 27893038. DOI: 10.1001/jamaoncol.2016.5281

62 Jovanovic B, Mayer IA, Mayer EL, Abramson VG, Bardia A, Sanders ME, Kuba MG, Estrada MV, Beeler JS, Shaver TM, Johnson KC, Sanchez V, Rosenbluth JM, Dillon PM, ForeroTorres A, Chang JC, Meszoely IM, Grau AM, Lehmann BD, Shyr Y, Sheng Q, Chen SC, Arteaga CL and Pietenpol JA: A randomized phase II neoadjuvant study of cisplatin, paclitaxel with or without everolimus in patients with stage II/III triplenegative breast cancer (TNBC): Responses and long-term outcome correlated with increased frequency of DNA damage response gene mutations, TNBC subtype, AR status, and Ki67. Clin Cancer Res 23(15): 4035-4045, 2017. PMID: 28270498. DOI: 10.1158/1078-0432.CCR-16-3055

63 Niemeier LA, Dabbs DJ, Beriwal S, Striebel JM and Bhargava $\mathrm{R}$ : Androgen receptor in breast cancer: expression in estrogen receptor-positive tumors and in estrogen receptor-negative tumors with apocrine differentiation. Mod Pathol 23(2): 205212, 2010. PMID: 19898421. DOI: 10.1038/modpathol.2009.159

64 Barton VN, D'Amato NC, Gordon MA, Christenson JL, Elias A and Richer JK: Androgen receptor biology in triple negative breast cancer: a case for classification as AR+ or quadruple negative disease. Horm Cancer 6(5-6): 206-213, 2015. PMID: 26201402. DOI: $10.1007 / \mathrm{s} 12672-015-0232-3$

65 Traina TA, Miller K, Yardley DA, Eakle J, Schwartzberg LS, O'Shaughnessy J, Gradishar W, Schmid P, Winer E, Kelly C, Nanda R, Gucalp A, Awada A, Garcia-Estevez L, Trudeau ME, Steinberg J, Uppal H, Tudor IC, Peterson A and Cortes J: Enzalutamide for the treatment of androgen receptor-expressing triple-negative breast cancer. J Clin Oncol 36(9): 884-890, 2018. PMID: 29373071. DOI: 10.1200/JCO.2016.71.3495

66 Bonnefoi H, Grellety T, Tredan O, Saghatchian M, Dalenc F, Mailliez A, L'Haridon T, Cottu P, Abadie-Lacourtoisie S, You B, Mousseau M, Dauba J, Del Piano F, Desmoulins I, Coussy F, Madranges N, Grenier J, Bidard FC, Proudhon C, MacGrogan G, Orsini C, Pulido $M$ and Gonçalves A: A phase II trial of abiraterone acetate plus prednisone in patients with triplenegative androgen receptor positive locally advanced or metastatic breast cancer (UCBG 12-1). Ann Oncol 27(5): 812818, 2016. PMID: 27052658. DOI: 10.1093/annonc/mdw067

67 De Vos M, Schreiber V and Dantzer F: The diverse roles and clinical relevance of PARPs in DNA damage repair: current state of the art. Biochem Pharmacol 84(2): 137-146, 2012. PMID: 22469522. DOI: $10.1016 /$ j.bcp.2012.03.018

68 Krishnakumar R and Kraus WL: The PARP side of the nucleus: molecular actions, physiological outcomes, and clinical targets. Mol Cell 39(1): 8-24, 2010. PMID: 20603072. DOI: 10.1016/ j.molcel.2010.06.017

69 Eustermann S, Wu WF, Langelier MF, Yang JC, Easton LE, Riccio AA, Pascal JM and Neuhaus D: Structural basis of detection and signaling of DNA single-strand breaks by human PARP-1. Molecular Cell 60(5): 742-754, 2015. PMID: 26626479. DOI: 10.1016/j.molcel.2015.10.032

70 Dawicki-McKenna JM, Langelier MF, DeNizio JE, Riccio AA, Cao CD, Karch KR, McCauley M, Steffen JD, Black BE and Pascal JM: PARP-1 activation requires local unfolding of an 
autoinhibitory domain. Mol Cell 60(5): 755-768, 2015. PMID: 26626480. DOI: 10.1016/j.molcel.2015.10.013

71 Satoh MS and Lindahl T: Role of poly(ADP-ribose) formation in DNA repair. Nature 356(6367): 356-358, 1992. PMID: 1549180. DOI: $10.1038 / 356356 \mathrm{a} 0$

72 Lord CJ and Ashworth A: PARP inhibitors: synthetic lethality in the clinic. Science 355(6330): 1152-1158, 2017. PMID: 28302823. DOI: $10.1126 /$ science.aam7344

73 Llombart-Cussac A, Bermejo B, Villanueva C, Delaloge S, Morales S, Balmaña J, Amillano K, Bonnefoi H, Casas A, Manso L, Roché H, Gonzalez-Santiago S, Gavilá J, SánchezRovira P, Di Cosimo S, Harbeck N, Charpentier E, Garcia-Ribas I, Radosevic-Robin N, Aura C and Baselga J: SOLTI NeoPARP: a phase II randomized study of two schedules of iniparib plus paclitaxel versus paclitaxel alone as neoadjuvant therapy in patients with triple-negative breast cancer. Breast Cancer Res Treat 154(2): 351-357, 2015. PMID: 26536871. DOI: 10.1007/ s10549-015-3616-8

74 Kummar S, Wade JL, Oza AM, Sullivan D, Chen AP, Gandara DR, Ji J, Kinders RJ, Wang L, Allen D, Coyne GO, Steinberg $\mathrm{SM}$ and Doroshow JH: Randomized phase II trial of cyclophosphamide and the oral poly (ADP-ribose) polymerase inhibitor veliparib in patients with recurrent, advanced triplenegative breast cancer. Invest New Drugs 34(3): 355-363, 2016. PMID: 26996385. DOI: 10.1007/s10637-016-0335-x

75 Gherardi E, Birchmeier W, Birchmeier C and Vande Woude G: Targeting MET in cancer: rationale and progress. Nat Rev Cancer 12(2): 89-103, 2012. PMID: 22270953. DOI: 10.1038/ nrc3205

76 Beviglia L, Matsumoto K, Lin CS, Ziober BL and Kramer RH: Expression of the c-Met/HGF receptor in human breast carcinoma: Correlation with tumor progression. Int $\mathrm{J}$ Cancer 74(3): 301-309, 1997. PMID: 9221809. DOI: 10.1002/(sici) 1097-0215(19970620)74:3<301::aid-ijc12>3.0.co;2-e

77 Jin L, Fuchs A, Schnitt SJ, Yao Y, Joseph A, Lamszus K, Park M, Goldberg ID and Rosen EM: Expression of scatter factor and c-met receptor in benign and malignant breast tissue. Cancer 79(4): 749-760, 1997. PMID: 9024713. DOI: 10.1002/(sici) 1097-0142(19970215)79:4<749::aid-cncr12>3.0.co;2-\#
78 Lengyel E, Prechtel D, Resau JH, Gauger K, Welk A, Lindemann K, Salanti G, Richter T, Knudsen B, Vande Woude GF and Harbeck N: C-Met overexpression in node-positive breast cancer identifies patients with poor clinical outcome independent of Her2/neu. Int J Cancer 113(4): 678-682, 2005. PMID: 15455388. DOI: 10.1002/ijc.20598

79 Raghav KP, Wang W, Liu S, Chavez-MacGregor M, Meng X, Hortobagyi GN, Mills GB, Meric-Bernstam F, Blumenschein GR $\mathrm{Jr}$ and Gonzalez-Angulo AM: cMET and phospho-cMET protein levels in breast cancers and survival outcomes. Clin Cancer Res 18(8): 2269-2277, 2012. PMID: 22374333. DOI: 10.1158/10780432.CCR-11-2830

80 Tuck AB, Park M, Sterns EE, Boag A and Elliott BE: Coexpression of hepatocyte growth factor and receptor (Met) in human breast carcinoma. Am J Pathol 148(1): 225-232, 1996. PMID: 8546209.

81 Yamashita J, Ogawa M, Yamashita S, Nomura K, Kuramoto M, Saishoji T and Shin S: Immunoreactive hepatocyte growth factor is a strong and independent predictor of recurrence and survival in human breast cancer. Cancer Res 54(7): 1630-1633, 1994. PMID: 8137271.

82 Yakes FM, Chen J, Tan J, Yamaguchi K, Shi Y, Yu P, Qian F, Chu F, Bentzien F, Cancilla B, Orf J, You A, Laird AD, Engst S, Lee L, Lesch J, Chou YC and Joly AH: Cabozantinib (XL184), a novel MET and VEGFR2 inhibitor, simultaneously suppresses metastasis, angiogenesis, and tumor growth. Mol Cancer Ther 10(12): 2298-2308, 2011. PMID: 21926191. DOI: 10.1158/15357163.MCT-11-0264

83 Tolaney SM, Ziehr D R, Guo H, Ng MR, Barry WT, Higgins MJ, Isakoff SJ, Brock JE, Ivanova EV, Paweletz CP, Demeo MK, Ramaiya NH, Overmoyer BA, Jain RK, Winer EP and Duda DG: Phase II and biomarker study of cabozantinib in metastatic triple-negative breast cancer patients. Oncologist 22(1): 25-32, 2016. PMID: 27789775. DOI: 10.1634/ theoncologist.2016-0229

Received August 4, 2019 Revised September 2, 2019 Accepted September 3, 2019 